University of Nebraska - Lincoln

DigitalCommons@University of Nebraska - Lincoln

\title{
The reproductive biology and effective pollinators of the endangered beardtongue Penstemon penlandii (Scrophulariaceae)
}

\author{
Vincent J. Tepedino \\ USDA ARS \\ Sedonia D. Sipes \\ Utah State University \\ Terry L. Griswold \\ Utah State University, terry.griswold@ars.usda.gov
}

Follow this and additional works at: https://digitalcommons.unl.edu/usdaarsfacpub

Part of the Agricultural Science Commons

Tepedino, Vincent J.; Sipes, Sedonia D.; and Griswold, Terry L., "The reproductive biology and effective pollinators of the endangered beardtongue Penstemon penlandii (Scrophulariaceae)" (1999). Publications from USDA-ARS / UNL Faculty. 231.

https://digitalcommons.unl.edu/usdaarsfacpub/231

This Article is brought to you for free and open access by the U.S. Department of Agriculture: Agricultural Research Service, Lincoln, Nebraska at DigitalCommons@University of Nebraska - Lincoln. It has been accepted for inclusion in Publications from USDA-ARS / UNL Faculty by an authorized administrator of DigitalCommons@University of Nebraska - Lincoln. 


\title{
The reproductive biology and effective pollinators of the endangered beardtongue Penstemon penlandii (Scrophulariaceae)
}

\author{
Vincent J. Tepedino ${ }^{1,2}$, Sedonia D. Sipes ${ }^{2}$, and Terry L. Griswold ${ }^{1,2}$ \\ ${ }^{1}$ USDA ARS Bee Biology and Systematics Laboratory, Utah State University, Logan, UT, USA \\ ${ }^{2}$ Utah State University, Department of Biology, Logan, UT, USA
}

Received March 23, 1998

Accepted February 16, 1999

\begin{abstract}
Penland's beardtongue, a rare endemic plant of the Colorado Plateau, displays a mixed breeding system. Plants are partially self-compatible but set more fruits when cross-pollinated than when self-pollinated. Fruit production is significantly increased by pollinators. However, in two years of study there was no indication that fruit set was being limited by inadequate pollinator visitation. Pollinator effectiveness was judged by correlating bee behavior at the flowers with analysis of the pollen carried on bee bodies. The most important pollinators were native megachilid bees, particularly in the genus Osmia. The bees that pollinate Penland's beardtongue are essential to its reproduction and must be preserved along with this rare plant.
\end{abstract}

Key words: Scrophulariaceae, Penstemon, Osmia, Bombus. - Pollination, breeding system, bees, pollinator effectiveness. Rare plant, conservation, reproduction.

Species of Penstemon (Scrophulariaceae) vary greatly in their pollination systems. Pollinators include hummingbirds, butterflies, bees, wasps, and flies (Kampny 1995). That Penstemon also exhibits great interspecific diversity in floral morphology, which is frequently pollinator correlated, cannot be entirely coincidental. For example, species pollinated primarily by hummingbirds, such as $P$. eatonii and $P$. centranthifolius, are red (a color more attractive to birds than to insects), and have narrow, pendant corollas that favor access by hummingbirds but not by most insects (Straw 1956, Bateman 1980). In contrast, corollas pollinated primarily by bees and wasps, such as those of $P$. palmeri or $P$. spectabilis, tend to be blue, pink, or purple and have wide, enlarged ventral lobes that serve as insect landing platforms (Straw 1956). Presumably there is an evolutionary explanation for the presence of such floral "syndromes".

The applicability of the floral syndrome concept to Penstemon species has been recently questioned (i.e. Mitchell 1988) because field studies usually reveal a diversity of flower visitors. However, a visitor does not a pollinator make. Plants may be pollinated effectively and consistently by only a few of the species that visit them. Unfortunately, it is often difficult to distinguish visitors from pollinators without experimentation. The preferred method of experimentation compares 
the fruit and seed production from controlled flower visits by abundant visitors (Motten et al. 1981, Tepedino 1981, Sugden 1986). Such an approach is precluded in studies of rare plants because natural pollination and fruit production must be denied to large numbers of flowers.

It is particularly important to identify the pollinators and pollinator requirements of allogamous rare plants. Rare plant species which depend on pollinators, and which can ill afford to forego reproductive opportunities, may best be preserved by instituting management practices that protect pollinators as well as plants. Conservationists must know which (if any) floral visitors should receive priority for monitoring and protection in their plans for plant recovery (e.g. Sipes and Tepedino 1995).

Here we report on the reproductive biology of Penstemon penlandii (Weber 1986), a perennial herb in the section Glabri (Rydberg) Pennell, listed as endangered under the United States' Endangered Species Act. $P$. penlandii has attributes associated with bee pollination: up to 30 blue to purple, bilaterally symmetric, nectar- and pollen-producing flowers are produced on an erect stem. However, for several reasons, the pollination of such rare plants may not conform to their floral syndrome. For example, as a plant taxon becomes increasingly rare, it may recruit fewer visits from its "normal" suite of pollinators (Levin 1971, Karron 1987) and more visits from atypical species (Tepedino 1979). Moreover, some rare plant species are found in habitats outside the ranges of their "proper" pollinators (Sipes and Tepedino 1996, Barnes 1996). In either case, the rare plant may be serviced by pollinators other than those suggested by its floral morphology. Our objectives were to describe the breeding system and floral visitors of $P$. penlandii, and to estimate and compare the effectiveness of those visitors as pollinators. We used a less intrusive, but more painstaking and infrequently employed approach that combines observations of insects on the flowers with microscopic examination of pollen deposited on their bodies (Bohart and Nye 1960, Beattie et al. 1973).

\section{Materials and methods}

Study site. Penstemon penlandii is known only from one area approximately $16 \mathrm{~km}$ east of the town of Kremmling in Grand Country, Colorado, USA. Within this area, the species is locally abundant on seleniferous shales of the Troublesome Formation (Anderson and Jordan 1992). Most known $P$. penlandii individuals are concentrated along several dirt roadsides within an area of $6 \mathrm{~km}^{2}$. The plant community is dominated by grasses and mixed shrubs, including the genera Artemisia, Chrysothamnus, and Purshia. Associated herbs include Astragalus spp., Eriogonum spp., Lupinus sp., and the common congener Penstemon caespitosus. We studied $P$. penlandii on private land and on land administered by the Bureau of Land Management. We were forbidden collection of any voucher material by the U. S. Fish and Wildlife Service because of the plant's endangered status.

Breeding system. Field studies were carried out during June and July of consecutive flowering seasons. In both years, we studied the structure and phenology of $P$. penlandii flowers to determine the timing of pollen dehiscence and stigma receptivity. In 1991, we chose 19 plants and bagged unopened buds with $1 \mathrm{~mm}$ mesh nylon tulle to exclude pollinators in a preliminary examination of the breeding system. Flowers received one of the following treatments: 1) no manipulation (autogamy or parthenogenesis), 2) self-pollination with pollen from another flower on the same plant (geitonogamy), 3) cross-pollination with a pollen donor at least 10 meters away (xenogamy), or 4) unbagged, unmanipulated controls. Not every plant received all four treatments because the experiment was begun late in the flowering season of the first year when plants with four or more unopened buds were difficult to locate. All treated flowers except controls were bagged throughout anthesis.

To insure that the self- and cross-pollination treatments occurred within the time of stigma receptivity, we repeated all hand pollinations on the first, second, and third days of anthesis. Flowers were pollinated manually before $10: 30 \mathrm{~h}$ 
to insure that donor pollen would be available (see below). Freshly dehisced donor anthers were collected with forceps and touched to recipient stigmas. Microscopic examination confirmed pollen transfer.

Flowers were monitored for fruit set at frequent intervals after anthesis. Fruit set among treatments was not compared with statistical tests due to the uneven distribution of treatments across plants. Many fruits were lost to frugivory by ground squirrels (probably Spermophilus elegans Kennicott) or other causes prior to harvesting, so seeds per fruit could not be compared.

Breeding system experiments were repeated at the beginning of the flowering season (early June) of 1992 on twenty plants. On each plant, four buds from one bagged inflorescence were each randomly assigned one of the four different treatments; thus each plant received all four treatments. Treatments were the same as in 1991 with the following exceptions. To examine the effects of outcrossing distances on reproductive success, two cross-pollination treatments were applied. For near out-crosses, we chose pollen donors from between 10 and 20 meters from the recipient plant. For far out-crosses, pollen donors were chosen from approximately $1.5 \mathrm{~km}$ away. In 1992, control flowers were marked on separate plants adjacent to the bagged plants. Fruit set was recorded for treated flowers and analyzed with a contingency table. Ground squirrels again harvested many fruits and prevented us from estimating seed set.

We determined whether the timing of stigma receptivity corresponded to the presumptive female phase of the flower (style tip curved downwards below stamens from its early position behind stamens and parallel to corolla tube), by experimentally cross-pollinating flowers of different ages in 1992. Ten of the twenty plants used for the breeding system experiments were chosen, and additional inflorescences with at least 3 unopened buds were bagged. Flower buds were randomly assigned to be cross-pollinated on either the first, second, or third day of anthesis. Fruit set among these treatments was compared using a contingency table.

To study the degree to which fruit set in $P$. penlandii was pollen limited, we exposed flowers to pollinator visitation for different durations. On June 10, 1992 one bud on each of forty plants was marked and bagged. To ensure synchronous treatment, we chose buds that would open the following day. Flowers were checked daily, and when the style curved downward (judged to be the time of stigma receptivity), the flower was unbagged for either one day, two days, three days, or the remainder of anthesis (controls). After the interval of exposure, flowers were rebagged for the remainder of anthesis. We repeated this experiment in an area approximately $1 \mathrm{~km}$ away from the first area on June 21. For both trials, fruit set among the treatments was compared using a contingency table. For this and all other statistical tests we use a significance level of $\mathrm{P}=0.05$.

Insect visitors. In 1991 and 1992, we observed and collected insect visitors to the flowers of $P$. penlandii for 1 hour intervals, starting at approximately $08: 30 \mathrm{~h}$ and continuing every two to three hours until activity ceased (approximately 17:00 h). Insect specimens were later identified and deposited in the G. E. Bohart Museum of the USDA ARS Bee Biology and Systematics Laboratory in Logan, Utah.

In 1992, we measured the number of insect visits per $P$. penlandii flower during two thirtyminute sessions, one in the morning and one in the afternoon of June 19. Additionally, on June 26, 27, and 28 , visitation rates were measured during two concurrent 30-60 minute sessions conducted by two observers. At all sessions, the number of open flowers was recorded for 3 to 5 observation plants. When a flower visitor was observed, we recorded the time of visitation, the taxon of the visitor (to the lowest level possible), the plant(s) visited, and the number of flowers visited on each plant. We calculated means for visits/plant/hour, and visits/ flower/hour.

Pollinator effectiveness. To estimate the relative effectiveness of the different insect visitors as pollinators, we observed their behavior on the nototribic flowers. In particular, we tried to determine whether the insects collected pollen, nectar, or both, and whether they contacted the anthers and stigma. Additionally, the collected specimens were scored in the laboratory for the abundance and placement of Penstemon pollen. We directly counted the number of Penstemon pollen grains present on selected body parts (Fig. 2a) of one bee, then estimated the number of grains on subsequent specimens by comparison with this 
exemplar. We estimated pollen grain number on the head, thorax, and abdomen of each insect visitor (excluding scopal pollen).

For genera with $\geq 6$ individuals we compared total number of pollen grains on bodies (excluding scopa) among genera using a Kruskal-Wallis test (data were not normally distributed). To examine the relationship between body size and pollen placement, we measured the length of individual bees and placed each species in one of four size classes ( $<6 \mathrm{~mm}, 6-8 \mathrm{~mm},>8-10 \mathrm{~mm}$, and $>10 \mathrm{~mm})$ based on mean length. We compared the number of pollen grains on bodies among the four size classes using a Kruskal-Wallis test.

A more detailed analysis of pollen placement was conducted on the most abundant visitor, Osmia brevis. To see if $O$. brevis individuals picked up pollen consistently on certain body parts, we compared the number of pollen grains on several major body segments (Fig. 2a) using a Friedman test which controlled for bees that were at different stages of foraging trips at the time of their capture.

Pollen collection. To estimate visitor fidelity, the percentage of Penstemon pollen in the scopal loads of female bees was determined by examining a sample of scopal pollen stained with fuchsin red in glycerin under a compound microscope (100X). Several transects through each slide were taken until five hundred pollen grains were counted and classified as belonging either to Penstemon or other taxa. For bee genera with large enough sample sizes, we compared the percentage of Penstemon pollen in the scopa among genera using a KruskalWallis test. Because $P$. penlandii overlaps in flowering time with $P$. caespitosus, and we were able to identify pollen only to the level of genus, some pollen may have come from the latter taxon.

\section{Results}

Floral morphology. Penstemon penlandii flowers are functionally protandrous. Typically, anthers of the longer, more distal, stamens begin to dehisce at 09:00 to 09:30 on the first day of anthesis while the shorter, more basal, pair dehisces later the same day, between 10:30 and 13:00. By the end of the first day of anthesis, little or no pollen remains in the anthers. Prior to this time, the style lies flush against the upper surface of the corolla tube, above the stamens. The stigma is not in an optimal position to contact probing insects until the second or third day of anthesis, when it is exposed as the style bends downward. Corollas of most flowers wither and fall off by the fourth day after anthesis.

Breeding system. Penstemon penlandii set little fruit in the absence of a pollinator (Tables $1 \mathrm{a}, \mathrm{b})$. In the two years, only $7-17 \%$ of bagged, unmanipulated flowers produced fruit. Breeding system treatments differed significantly in 1992. A partition of the contingency table showed that only the comparison between autogamy and the other treatments was significant. There was no significant difference in fruit set among breeding system treatments that required a pollinator: Thus, although $P$. penlandii requires a pollinator for most of its fruit set, it is partially selfcompatible, and consecutive within-plant flower visits may produce fruit. No difference in fruit set was observed between near and far cross-pollinations. Nor was there any indication of pollinator limitation of fruit set: fruit set of open-pollinated controls was indistinguishable from cross-pollination treatments (Table 1b).

Some stigmas of $P$. penlandii are physiologically receptive from the beginning anthesis, before the style has curved downwards, to at least the third day after anthesis (Table 1c). We found no significant differences in fruit set among flowers cross-pollinated on either the first, second, or third day of anthesis $\left(x^{2}=1.85, \mathrm{df}=2, \mathrm{P}>0.3\right)$. Although individuals are self-compatible and the stigmas are physiologically receptive at the time of pollen dehiscence, within-flower pollinations are minimized by the early position of the stigma.

Only one day of exposure to pollinators was sufficient for fruit set. We found no significant differences among flowers exposed to pollinators for one, two, or three days, or with controls, in either of the two trials (Table 2). During the first trial, day 1 was warm and sunny while days two and three were cold and rainy. Thus, trial one may not 
Table 1. Comparison of $P$. penlandii fruit set among: a) three breeding system treatments and controls in 1991 ; b) four breeding system treatments and controls in $1992\left(\chi^{2}=17.4, \mathrm{df}=4,0.005>\mathrm{P}>0.001\right.$; partition, autogamy vs. all others, $\chi^{2}=14.7, \mathrm{df}=1, \mathrm{P}<0.001$ ); and $\mathrm{c}$ ) flowers cross-pollinated on either the first, second, or third day of anthesis in 1992. Original $n=10$; some data missing due to frugivory

\begin{tabular}{llllll}
\hline a) & Autogamy & Geitonogamy & Cross-pollination & $\begin{array}{l}\text { Control } \\
\text { (Open-pollinated) }\end{array}$ \\
Fruit & 2 & 7 & 17 & 12 & \\
No Fruit & 27 & 13 & 19 & 27 & Control \\
\hline b) & Autogamy & Geitonogamy & $\begin{array}{l}\text { Near Cross- } \\
\text { pollination }\end{array}$ & $\begin{array}{l}\text { Far Cross- } \\
\text { pollination }\end{array}$ & (Open-pollinated) \\
& & & 13 & 13 & 13 \\
Fruit & 3 & 9 & 5 & 5 & 5 \\
No Fruit & 15 & 9 & $3^{\text {rd }}$ Day & & \\
\hline c) & $1^{\text {st }}$ Day & $2^{\text {nd }}$ Day & 4 & & \\
Fruit & 7 & 4 & 4 & & \\
No Fruit & 2 & 4 & & & \\
\hline
\end{tabular}

Table 2. Comparison of flowers exposed to pollinators for one, two, or three days. Flowers were bagged prior to anthesis and then again after the exposure period. Original $\mathrm{n}=10$; some data lost due to frugivory. No comparison was significant (trial 1: $\chi^{2}=1.88$, $\mathrm{df}=3, \mathrm{P}>0.5$; Trial $2: \chi^{2}=4.99, \mathrm{df}=3, \mathrm{P}>0.1$ )

\begin{tabular}{lllll}
\hline & Open 1 day & Open 2 days & Open 3 days & Control \\
\hline Trial 1 & & & & \\
$\quad$ Fruit & 6 & 4 & 7 & 6 \\
No Fruit & 3 & 3 & 1 & 2 \\
Trial 2 & & 2 & 5 & 2 \\
Fruit & 5 & 7 & 5 & 8 \\
No Fruit & 3 & & & \\
\hline
\end{tabular}

have been a rigorous test in that few pollinators were likely to be present during days two and three. During the second trial, all days were warm and sunny, yet there seemed to be no benefit for flowers to open for more than one day.

Insect visitation. As with some other Penstemon species (Lawson et al. 1989, Nielson 1998), $P$. penlandii flowers are visited by a diverse array of pollen and nectar feeding insects (Table 3). Visitor guild composition varied greatly between 1991 and 1992. For example, bees of the genera Anthophora, Anthocopa, and Hoplitis were collected only in 1991. Although the most common visitors during both years were solitary bees of the genus Osmia, different species were present in the two years. In 1991 the most abundant visitor was $O$. brevis, a species not collected in 1992, whereas $O$. giliarum was collected only in 1992. Bumble bees (Bombus spp.) were present in both years, but we only collected a few specimens so as not to deplete the number of queens forming new colonies.

During a total of 5.8 observation hours in 1992, $P$. penlandii plants received an average of $6.5( \pm 5.3)$ visits per hour, whereas individual flowers received an average of 1.1 $( \pm 0.8)$ visits per hour $(n=8$ observation sessions). Most plant visits were made by Osmia spp. (44\%) followed by other bees (32\%) (Fig. 1). However, individual flowers 
Table 3. Aculeate hymenopteran visitors to Penstemon penlandii collected in 1991 and 1992

\begin{tabular}{|c|c|c|c|}
\hline Taxon & number of individuals & years collected & size class \\
\hline \multicolumn{4}{|l|}{ Hymenoptera } \\
\hline \multicolumn{4}{|l|}{ Andrenidae } \\
\hline Heterosarus bakeri (Ckll) & 4 & 1991 & $<6 \mathrm{~mm}$ \\
\hline \multicolumn{4}{|l|}{ Apidae } \\
\hline Anthophora bomboides Kirby & 5 & 1991 & $>10 \mathrm{~mm}$ \\
\hline A. ursina $\mathrm{Cr}$. & 6 & 1991 & $>10 \mathrm{~mm}$ \\
\hline Bombus appositus $\mathrm{Cr}$. & 3 & 1992 & $>10 \mathrm{~mm}$ \\
\hline B. huntii Greene & 10 & 1991, 1992 & $>10 \mathrm{~mm}$ \\
\hline Ceratina nanula Ckll. & 5 & 1992 & $<6 \mathrm{~mm}$ \\
\hline C. neomexicana Ckll. & 3 & 1991,1992 & $6-8 \mathrm{~mm}$ \\
\hline Synhalonia fulvitarsis (Cr.) & 1 & 1992 & $>10 \mathrm{~mm}$ \\
\hline \multicolumn{4}{|l|}{ Colletidae } \\
\hline Hylaeus sp. & 1 & 1992 & $<6 \mathrm{~mm}$ \\
\hline \multicolumn{4}{|l|}{ Halictidae } \\
\hline Dufourea (new species) & 1 & 1992 & $<6 \mathrm{~mm}$ \\
\hline \multicolumn{4}{|l|}{ Megachilidae } \\
\hline Anthocopa abjecta (Cr.) & 5 & 1991 & $>8-10 \mathrm{~mm}$ \\
\hline A. elongata (Mich.) & 1 & 1991 & $6-8 \mathrm{~mm}$ \\
\hline Hoplitis producta complex & 4 & 1991 & $6-8 \mathrm{~mm}$ \\
\hline Osmia (Acanthosmioides) sp. & 1 & 1992 & $>8-10 \mathrm{~mm}$ \\
\hline O. albolateralis Ckll. & 2 & 1992 & $>8-10 \mathrm{~mm}$ \\
\hline O. atrocyanea Ckll. & 1 & 1992 & $>8-10 \mathrm{~mm}$ \\
\hline O. brevis $\mathrm{Cr}$ & 30 & 1991 & $>8-10 \mathrm{~mm}$ \\
\hline O. bruneri Ckll. & 2 & 1991,1992 & $>8-10 \mathrm{~mm}$ \\
\hline O. calla Ckll. & 3 & 1991 & $6-8 \mathrm{~mm}$ \\
\hline O. cyaneonitens Ckll. & 4 & 1991 & $>10 \mathrm{~mm}$ \\
\hline O. gilarium Ckll. & 9 & 1992 & $>8-10 \mathrm{~mm}$ \\
\hline O. ednae (Ckll.) & 2 & 1991 & $6-8 \mathrm{~mm}$ \\
\hline O. nigrifrons $\mathrm{Cr}$. & 1 & 1992 & $>10 \mathrm{~mm}$ \\
\hline o. parkeri Gwld. & 3 & 1991 & $>8-10 \mathrm{~mm}$ \\
\hline O. physariae Ckll. & 1 & 1992 & $6-8 \mathrm{~mm}$ \\
\hline O. proxima $\mathrm{Cr}$. & 2 & 1992 & $>8-10 \mathrm{~mm}$ \\
\hline O. pusilla $\mathrm{Cr}$. & 1 & 1992 & $6-8 \mathrm{~mm}$ \\
\hline$O$. sp. & 1 & 1992 & $\begin{array}{l}\text { damaged, } \\
\text { not available }\end{array}$ \\
\hline \multicolumn{4}{|l|}{ Masaridae } \\
\hline Pseudomasaris vespoides (Cr.) & 6 & 1191,1992 & $>10 \mathrm{~mm}$ \\
\hline
\end{tabular}

were visited about equally by Osmia spp. (31.9\%), other bees (32.3\%), and Pseudomasaris wasps $(26.6 \%)$, because the latter tended to visit more flowers per plant. Other taxa made up less than $10 \%$ of flower visits.

Pollinator effectiveness. Most visitor taxa were uncommon and carried few or no
Penstemon pollen grains on their bodies, suggesting that they are not consistent or effective pollinators of $P$. penlandii. These non-pollinating visitors included most of the smaller hymenopterans $(<6 \mathrm{~mm})$, as well as the flies, butterflies and beetles (a complete list of taxa is available from the authors). Insects 


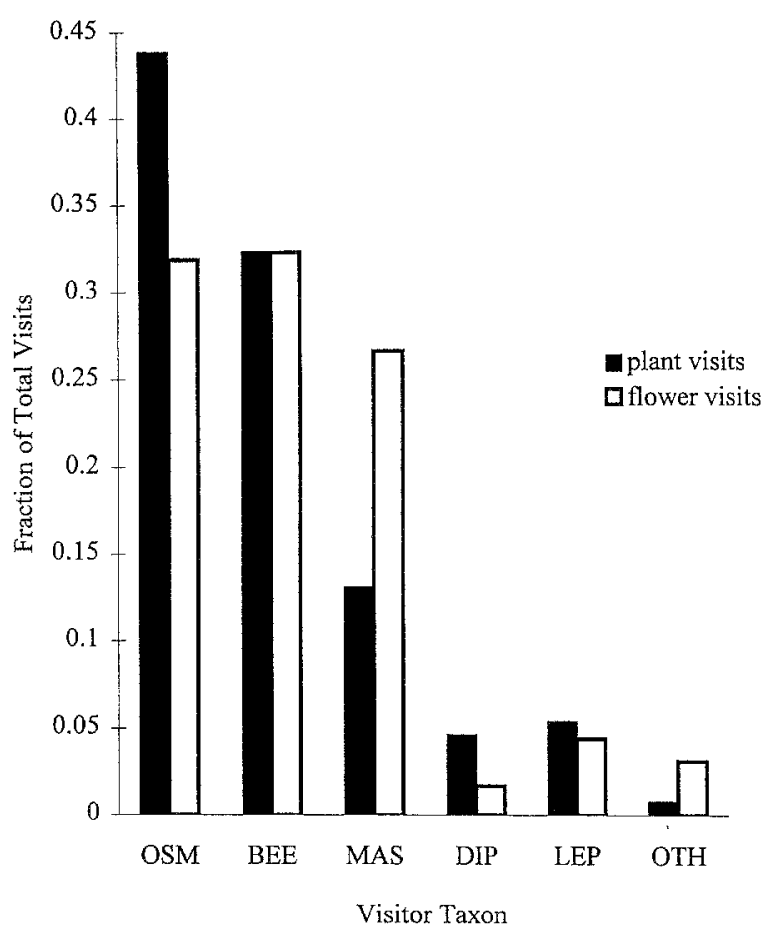

Fig. 1. Fraction of total plant and flower visits to $P$. penlandii by different insect visitors. $O S M$ Osmia, BEE other bees, MAS Pseudomasaris, DIP Diptera, LEP Lepidoptera, OTH other insects

that did carry Penstemon pollen on their bodies were species of the bee genera Anthocopa (2 species), Anthophora (2 species), Bombus (2 species), Hoplitis (1 species), Osmia (15 species), and the masarid wasp Pseudomasaris vespoides (Table 4). Of these, bees of the genus Osmia were the most frequently collected.

We compared the total number of pollen grains on the bodies of individuals of the five genera that had sample sizes $\geq 6$ individuals (Table 4). There was a significant difference in total body pollen among Anthocopa, Anthophora, Bombus, Osmia, and Pseudomasaris. We conducted Wilcoxon 2 Sample tests to compare the most common visitors, Osmia spp., to each of the other four genera. Only Bombus spp. had significantly less body pollen than Osmia.

The number of Penstemon pollen grains carried was related to body size of the
Table 4. Median number of pollen grains carried on bodies of Hymenoptera captured on $P$. penlandii in 1991 and 1992 grouped by genera. $N=$ sample size; Q1, Q3 $=1^{\text {st }}$ and $3^{\text {rd }}$ Quartiles, respectively. Median values with different superscripts are significantly different (Kruskal-Wallis Test, $\mathrm{P}<0.025$; Wilcoxon test, $\mathrm{P}<0.001$ )

\begin{tabular}{lllll}
\hline Genus & $\mathrm{N}$ & Median & $\mathrm{Q} 1$ & $\mathrm{Q} 3$ \\
\hline Anthocopa & 6 & $2725.5^{\mathrm{a}}$ & 1177 & 3361 \\
Anthophora & 12 & $2086.5^{\mathrm{a}}$ & 712.5 & 3031.8 \\
Bombus & 13 & $858^{\mathrm{b}}$ & 440 & 1750 \\
Osmia & 59 & $2486^{\mathrm{a}}$ & 1638 & 3248 \\
$\quad \begin{array}{l}\text { O. brevis } \\
\text { O. (non- }\end{array}$ & 29 & 3041 & 1878 & 3304 \\
$\quad 30$ & 2268 & 1588 & 2973 \\
$\quad$ brevis) & & & & \\
Pseudomasaris & 6 & $2132.1^{\mathrm{a}}$ & 1174 & 3820.3 \\
\hline
\end{tabular}

pollinator taxa (Table 5). We found a significant difference among the four size classes in total body pollen: individuals in the $>8-10 \mathrm{~mm}$ class carried the most pollen grains, followed by those in the $>10 \mathrm{~mm}$ class, the $6-8 \mathrm{~mm}$ class, and the $<6 \mathrm{~mm}$ class. Additional Wilcoxon tests showed that individuals in the $>8-10 \mathrm{~mm}$ size class had significantly more pollen on their bodies than did those in the $>10 \mathrm{~mm}$ class.

Pollen placement on the three main body parts varied according to the size class of the insect (Table 5): insects had significantly decreasing amounts of pollen on the head from the $>8 \mathrm{~mm}$ size classes to the $<6 \mathrm{~mm}$ size class. For the thorax, bees $>8-10 \mathrm{~mm}$ had significantly more pollen, and those $<6 \mathrm{~mm}$ had less, than the other size classes. Finally, the $<6 \mathrm{~mm}$ class had significantly fewer pollen grains on the abdomen than did all other classes. This pattern suggests pollen deposition on body parts according to the size of the insect: the largest insects do not crawl as deeply into the corolla tube and so contact the anthers (and stigma) primarily with the head rather than the thorax. In contrast, insects of the $8-10 \mathrm{~mm}$ size class contact the anthers primarily with their thorax.

To determine if the most abundant visitors (Osmia spp.) carried the most body pollen, we 
Table 5. Median number of pollen grains carried on three body parts of Hymenoptera grouped by body size. $\mathrm{N}=$ sample size. Medians differing in superscripts across rows are significantly different (Kruskal-Wallis and Wilcoxon Tests. Q1, Q3 $=1^{\text {st }}$ and $3^{\text {rd }}$ Quartiles, respectively)

\begin{tabular}{lllll}
\hline & \multicolumn{4}{c}{ Body Size $(\mathrm{mm})$} \\
Head & $<6$ & $6-8$ & $>8-10$ & $>10$ \\
\hline $\mathrm{N}$ & 10 & 15 & 55 & 36 \\
Median & $0^{\mathrm{b}}$ & $80^{\mathrm{b}}$ & $958^{\mathrm{a}}$ & $896.5^{\mathrm{a}}$ \\
Q1 & 0 & 13 & 592 & 609 \\
Q3 & 7 & 284 & 1425 & 2327.5 \\
\hline Thorax & & & & \\
$\mathrm{N}$ & 10 & 15 & 55 & 36 \\
Median & $0^{\mathrm{c}}$ & $159^{\mathrm{b}}$ & $1257^{\mathrm{a}}$ & $438^{\mathrm{b}}$ \\
Q1 & 0 & 37 & 929 & 69 \\
Q3 & 4 & 1138 & 1861 & 892 \\
\hline Abdomen & & & & \\
$\mathrm{N}$ & 10 & $12^{*}$ & $52^{*}$ & 36 \\
Median & $0^{\mathrm{b}}$ & $64^{\mathrm{a}}$ & $90.5^{\mathrm{a}}$ & $41.5^{\mathrm{a}}$ \\
Q1 & 0 & 27.5 & 42.5 & 9.1 \\
Q3 & 2.7 & 174 & 326.5 & 108 \\
\hline Total & & & & \\
$\mathrm{N}$ & 10 & $12^{*}$ & $52^{*}$ & 36 \\
Median & $2^{\mathrm{d}}$ & $410^{\mathrm{c}}$ & $2618.5^{\mathrm{a}}$ & $1779^{\mathrm{b}}$ \\
Q1 & 0 & 147.2 & 1845.5 & 695.5 \\
Q3 & 11 & 1884 & 3276 & 2910.1 \\
\hline Th & & &
\end{tabular}

* Three specimens with damaged abdomens omitted from analysis.

compared Osmia species with other taxa pooled into three size classes using Wilcoxon tests (Table 6). (The $<6 \mathrm{~mm}$ size class contained no Osmia species and was eliminated.) In the $6-8 \mathrm{~mm}$ size class, Osmia species carried more body pollen than Anthocopa elongata, Ceratina spp., and Hoplitis producta combined, but there were too few individuals for statistical analysis. In neither the $>8-10 \mathrm{~mm}$ size class, nor in the $>10 \mathrm{~mm}$ size class did Osmia species differ significantly from other taxa.

We analyzed the pattern of pollen placement on the body of the most abundant visitor species in 1991, O. brevis, to determine if these bees carried Penstemon pollen consistently on particular body parts (Table 7). There was a significant difference in number of pollen grains among the head, thorax, and abdomen (excluding scopae).

Most pollen was deposited along the central axis of $O$. brevis females (Fig. 2). There was a significant difference in number of pollen grains fround on different areas of the heads: most pollen was located on the frons and the supraclypeal area rather than on lateral structures (Fig. 2a,b). A significant difference

Table 7. Median number of pollen grains carried on three body parts by Osmia brevis. $\mathrm{N}=$ sample size, $\mathrm{Q} 1, \mathrm{Q} 3=1^{\text {st }}$ and $3^{\text {rd }}$ Quartiles, respectively. Medians followed by different superscripts are significantly different (Friedman Test)

\begin{tabular}{llll}
\hline & Head & Thorax & Abdomen \\
\hline N & 30 & 30 & $29^{*}$ \\
Median & $1347.5^{\mathrm{a}}$ & $1198.5^{\mathrm{a}}$ & $50^{\mathrm{b}}$ \\
Q1 & 859 & 908 & 38 \\
Q3 & 1674 & 1604 & 200 \\
\hline
\end{tabular}

*One specimen with damaged abdomen omitted from analysis.

Table 6. Median number of pollen grains carried on the body by Osmia species and other similar sized taxa, grouped by size category. $\mathrm{N}=$ sample size. Q1, Q3 $=1^{\text {st }}$ and $3^{\text {td }}$ Quartiles, respectively. There were no significant differences between groups within size classes $>8-10$ and $>10$ ( $P>0.05$, Wilcoxon Tests)

\begin{tabular}{lllllllll}
\hline & \multicolumn{4}{c}{ Osmia species } & \multicolumn{4}{c}{ Other Hymenoptera } \\
Size Class $(\mathrm{mm})$ & $\mathrm{N}$ & Median & Q1 & Q3 & N & Median & Q1 & Q3 \\
\hline $6-8$ & 7 & 1829 & 206 & 2247 & 5 & 138 & 137 & 408 \\
$>8-10$ & 47 & 2568 & 1813 & 3248 & 5 & 2820 & 2631 & 3361 \\
$>10$ & 5 & 2947 & 2678 & 3505 & 31 & 1476 & 682 & 2849.5 \\
\hline
\end{tabular}


V. J. Tepedino et al.: Pollination biology of Penland's Beardtongue

a
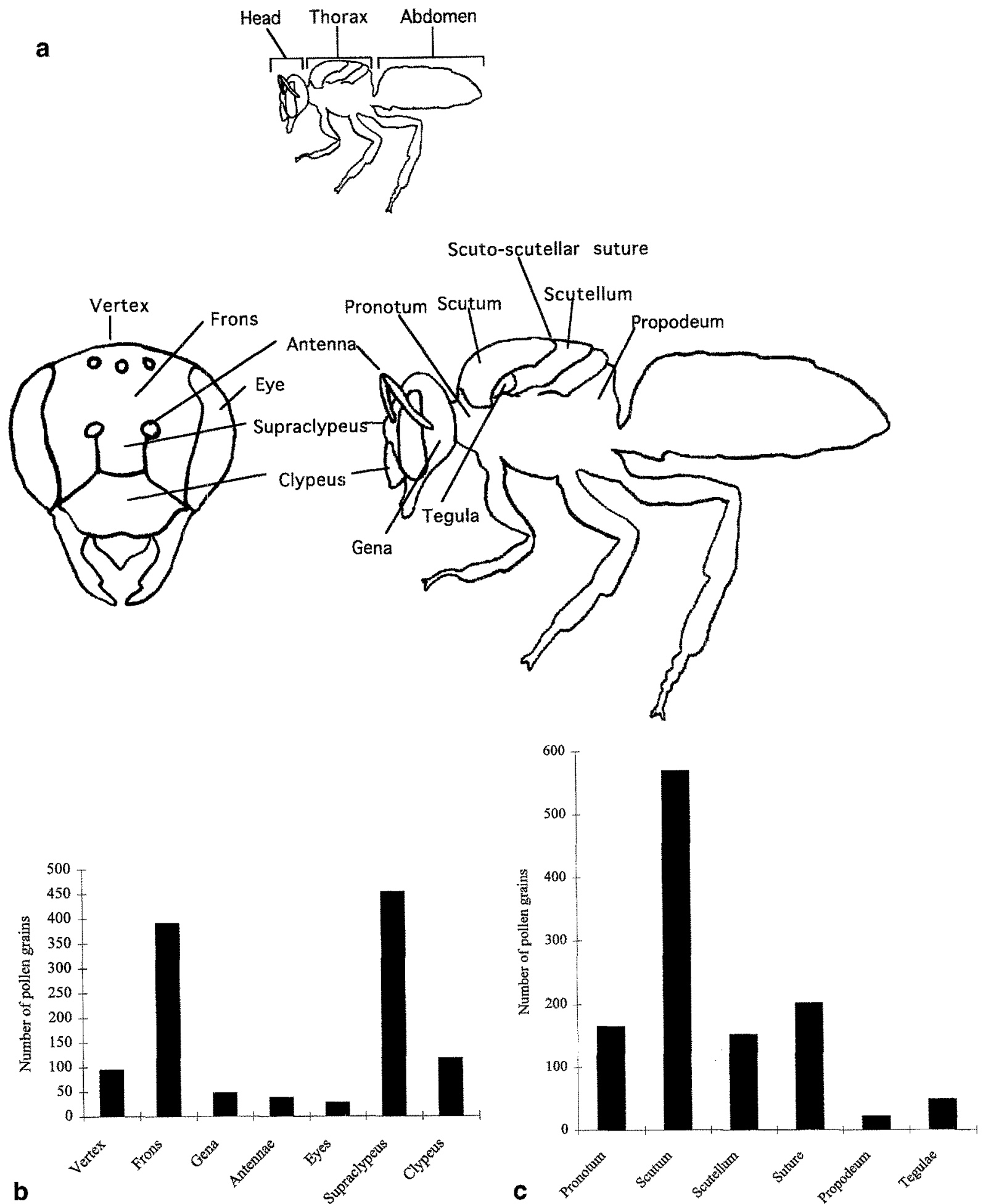

Fig. 2. a) Schematic diagram of body areas on which Penstemon pollen grains were counted. Median number of pollen grains counted on different parts of Osmia brevis b) heads, c) thoraces 
among areas on the thorax also was evident: again most pollen was centrally located, primarily on the scutum, with secondary amounts on the pronotum and scutellum (Fig. 2a,c). Our field observations of foraging $O$. brevis show that these central areas of the bees' head and thorax are also those most likely to contact the stigma of these nototribic flowers. We were unable to analyze other Osmia species as thoroughly due to small sample sizes, but $O$. brevis and other Osmia species pooled did not differ in total body pollen (Table 4, Wilcoxon test), and our field observations indicate that they forage similarly in flowers.

Pollen collection. The percentage of Penstemon pollen in the scopal pollen loads of bees varied among taxa. There was a significant difference among three genera with sample sizes $\geq 6$ (Osmia, Anthophora, Bombus) (Kruskal-Wallis test). Of these, Osmia was the most consistent collector of Penstemon pollen (median 99\%, Q1 $=98.2 \%, \mathrm{Q} 3=$ 99.6\%, $\mathrm{N}=44$ ). There was no significant difference in the percentage of Penstemon pollen carried in the scopa between the most abundant species $O$. brevis (median $=98.9 \%$, $\mathrm{Q} 1=98.5 \%, \mathrm{Q} 3=99.4 \%, \mathrm{~N}=24)$, and all other Osmia species pooled (median $=99.3 \%$, $\mathrm{Q} 1=90.7 \%, \mathrm{Q} 3=99.8 \%, \mathrm{~N}=20$ ) (Wilcoxon test). The pollen loads of other taxa also contained a high percentage of Penstemon pollen: Anthophora (median $87 \%, \mathrm{Q} 1=49 \%$, $\mathrm{Q} 3=91 \%, \quad \mathrm{~N}=6$ ), and Bombus (median $57.7 \%, \mathrm{Q} 1=33.8 \%, \mathrm{Q} 3=85.2 \%, \mathrm{~N}=4) . \mathrm{A}$ single Anthocopa elongata carried $100 \%$ Penstemon pollen in its scopa but two Hoplitis producta individuals with scopal loads averaged only $25 \%$ Penstemon pollen. No other bees carried scopal pollen. Pollen collected by the wasp $P$. vespoides is transported internally and was not analyzed.

\section{Discussion}

Two hypotheses have been offered to predict the reproductive characteristics of entomophi- lous flowering plant species. One suggests that rare plants are likely to be inferior competitors for pollinators with common species (Levin and Anderson 1970, Straw 1972, Bobisud and Neuhaus 1975). If true, rare plants should experience selection for breeding mechanisms that increase their chances of reproducing successfully when pollinators are inattentive, such as self-compatibility, autogamy, and/or apomixis (Levin and Anderson 1970, Levin 1971, Tepedino 1979, Karron 1989). In general, this scenario should best fit rare plants visited by high-energy and nutrient demanding pollinators such as bees. Because bees are central place foragers (Orians and Pearson 1979) that must provide nectar and pollen for their progeny as well as themselves, they are drawn to densely flowering plant species. Thus, blue/violet beardtongues such as $P$. penlandii that fit the "bee pollinated" syndrome may be especially vulnerable to pollinator inattention.

A second hypothesis (Kunin and Shmida 1997), predicts that rare plants compensate for their numerical disadvantage by producing larger, more attractive, flowers. This is a hypothesis we cannot test with our data, though we note that the flowers of $P$. penlandii, as well as those of some other rare beardtongues, $(P$. harringtonii, $P$. debilis, $P$. albomarginatus) are not especially large members of the genus.

In reality, the evidence supporting these expectations for rare plants is slim. Indeed, growing evidence suggests that rare plants are as likely to require pollinators as are common plants (Tepedino 1999). For some rare plants like Astragalus montii (Geer and Tepedino 1993) and Sclerocactus mesae-verdae (Tepedino et al., unpub.), the breeding system may indeed be following an escalating sequence from outcrossing to self-compatibility to autogamy. However, there is no indication that the incidence of any of these developments is greater for rare plants than it is for common ones. For example, $P$. penlandii is self-compatible, but not autogamous or apomictic to any extent. Rather, like other 
members of the genus that have been studied (Kampny 1995, Nielson 1998), both rare and common beardtongues require pollinators for sexual reproduction.

There are at least two reasons why rare plants in general, and $P$. penlandii in particular, may depend as much on pollinators as do common plants. First, if the decline in the number and size of populations is for anthropogenic reasons, as is frequently suspected (Fiedler and Ahouse 1992), that decline may be too rapid and too recent for a breeding system response to be evident. Current evidence seems not to require such an explantion: flowers of many rare plants including $P$. penlandii are visited by a variety of insects, and rarely exhibit the signs of pollinatorlimited fruit set expected from selection on the breeding system (Tepedino 1999).

A more likely explanation for the absence of any major modification of the breeding system mechanisms of $P$. penlandii and other species, is that many of these species are globally rare but locally abundant, rather than widespread with many sparse populations (Rabinowitz 1981). Indeed, during our two years of study, $P$. penlandii was one of the most abundant species in bloom. One would not expect selection for the modification of the breeding system of such species unless the flowers were unattractive. We found no such evidence. Open-pollinated flowers enjoyed fruit set as high as experimentally crosspollinated flowers (Table 1a,b) and there was no difference in fruit set between flowers exposed to pollinators for different numbers of days (Table 2). Finally, estimates of visitation rates showed that the average flower is visited several times per day, and that most visits were by pollinating taxa (Fig. 1).

Penstemon penlandii fits the "bee-pollinated" syndrome of other blue/violet members of the genus (Crosswhite and Crosswhite 1966, Lawson et al. 1989, Nielson 1998). Although the flowers are visited by many species of insects, only certain members of the Hymenoptera, especially bees, appear to be effective pollinators (Tables 3,4 ). These species tend to be $\geq 8 \mathrm{~mm}$, to collect substantial amount of Penstemon pollen in their scopal loads, and to carry much Penstemon pollen on the head and dorsal thorax, body parts that our observations suggest are likely to contact the stigma during foraging.

Most pollinators are members of a large guild of megachilid bee species, particularly in the genus Osmia (Table 3). Members of this guild exhibited intriguing occurrence patterns which demonstrate the importance of pollinator redundancy to flowering plants in general, and to rare plants, in particular (see below). Seventeen of 18 pollinator species were present only in one of the two years of our study. Part of this pattern is likely due to the uncommoness of many of these species, particularly the smaller ones, at the flowers of $P$. penlandii. However, some species, such as $O$. brevis and $O$. giliarum, were common in one year but absent in the other. This unexpected pattern of occurrence may be due to the differences in flowering times of $P$. penlandii between the years. In both years, we collected during the latter half of the flowering season. In 1991, this occurred during the first two weeks of July. In 1992, $P$. penlandii flowered during the month of June, but had ceased flowering by July; most of our collections were made in the last half of June. Thus, our collection dates did not overlap between years. Therefore, some of the between-year variation in Osmia species present on $P$. penlandii flowers may be attributable to differences in flowering times, and to our incomplete sampling during the 1991 season.

It is also possible that species such as $O$. brevis and $O$. giliarum are parsivoltine (a variable segment of a cohort requires more than one year to develop to adulthood), at least at higher elevations. Several species of Osmia bees are parsivoltine (Torchio and Tepedino 1982) and parsivoltinism could help drive the between-year differences in bee species composition, and might lead to year-to-year variation in pollinator abundances and fruit set. 
It is presently unclear how many of these Osmia species are specialized visitors of Penstemon flowers. Osmia cyaneonitens, thought to be quite rare until recently, has been collected only from Penstemon, on which it is presumed to be oligolectic (Lawson et al. 1989). The other 14 species visit an array of host plants, but their pollen preferences are unknown (Hurd 1979). However, there is a trend for some of them (including $O$. brevis, $O$. bruneri, $O$. ednae, $O$. proxima, and $O$. albolateralis) to be closely associated with Penstemon, and for at least some local populations to act as Penstemon specialists (Crosswhite and Crosswhite 1966, Moldenke and Neff 1974, Cripps and Rust 1989, Lawson et al. 1989). Our results support this trend: 95\% of Osmia scopal loads were composed of Penstemon pollen, indicating that these bees were foraging almost exclusively on Penstemon. It is of interest that three of these Osmia species which appear to prefer beardtongue flowers (O. brevis, $O$. cyaneonitens, $O$. ednae) have long proclinate hairs densely overhanging the frons which meet equally long, dorsally-directed hairs arising from the supraclypeus. In $O$. brevis the supraclypeus and frons are two regions with particularly high pollen counts (Fig. 3). These hairs may be pollen-collecting apparati that enable bees to more effectively exploit nototribic flowers, as has been reported by Müller (1996) for some central European species.

Although Osmia species were the most abundant and consistent pollinators of $P$. penlandii, other hymenopterans also likely contributed to its reproduction. Anthocopa abjecta and $A$. elongata are in the subgenus Atoposmia which is closely related to Osmia. Bees of this subgenus exhibit a strong preference for Penstemon (Hurd 1979). Anthocopa abjecta is of similar size as many of the Osmia species, and therefore may be of comparable importance to $P$. penlandii. However, like many Osmia species, this bee was only collected in one of the two years, suggesting that its flight times may not always overlap with $P$. penlandii flowering, or that its abundance varies from year to year.

Bumblebees (Bombus spp.) were common on $P$. penlandii flowers in both years, but we collected few specimens so as not to negatively impact their populations. Thus, their relative abundance in the collection of floral visitors is underestimated. Bumblebee workers tend to specialize at least for short periods of time while their hosts are abundant (Heinrich 1979); thus, they are likely important pollinators of $P$. penlandii.

The pollen-collecting wasp Pseudomasaris vespoides is an oligolege of Penstemon (Cooper 1952). This wasp exhibits specialized behavioral and morphological characteristics that allow it not only to collect Penstemon pollen efficiently, but also to pollinate Penstemon flowers (Torchio 1974). Specialized hairs on the dorsal thorax accumulate pollen and contact stigmas when it forages in Penstemon flowers. Pseudomasaris vespoides tended to visit more $P$. penlandii flowers per plant than did the bee pollinators and therefore may carry out more geitonogamous pollinations (De Jong et al. 1993). If P. penlandii suffers inbreeding depression when selfed, as do some plants with mixed-mating systems (Charlesworth and Charlesworth 1987), then pollinations by $P$. vespoides may result in less fit offspring relative to offspring from bee pollinations.

The suite of pollinators of $P$. penlandii is very similar to visitors of several other rare "bee syndrome" Penstemon species in the western U.S.. For example, the rare Nebraska endemic $P$. haydenii, is visited by approximately 50 insect taxa from 4 different orders, but is pollinated effectively only by the megachilid bees Osmia ( 3 spp., including $O$. cyaneonitens) and Hoplitis (1 sp.) (Lawson et al. 1989). Pollinators of the Colorado endemic $P$. harringtonii include $O$. brevis plus six other Osmia species, Bombus appositus, Anthophora bomboides, A. ursina, Hoplitis spp., Anthocopa spp., and Pseudomasaris vespoides (Nielson 1998). Osmia brevis and P. vespoides 
are also important pollinators of $P$. lemhiensis, a rare plant of southern Montana and Idaho (Ramstetter and Peterson 1984).

Conservation Implications. The flowers of the endangered $P$. penlandii are unlikely to produce fruits unless they are visited by certain hymenopterans, mainly native bees (Table 1). If land managers are to aid in the recovery of $P$. penlandii, they must ensure that local populations of these bees and wasps continue to thrive. That over 20 species pollinate $P$. penlandii should evoke guarded optimism rather than complacency. Much of this pollinator redundancy increases the likelihood that the plant will be reproductively successful each year, as suggested by the different suites of pollinators between two consecutive years (Table 3). It is the land manager's responsibility to foster such redundancy.

The presence of numerous pollinating taxa, especially the Osmia species, may be one reason why $P$. penlandii enjoyed full fruit set during this study. $P$. penlandii began flowering on different dates in 1991 and 1992; thus, this species experiences year-toyear variation in flowering time, at least occasionally. Moreover, the abundances and adult phenology of the various Osmia bees may vary from year to year, as has been shown for other pollinator guilds (Tepedino 1980, Cane and Payne 1993). The presence of numerous megachilid bee species increases the chances that at least one will be abundant when $P$. penlandii flowers. Bumblebees may afford further insurance against variable pollinator service because many species are active from spring until fall (Alford 1975). Therefore, $P$. penlandii may owe its reproductive success not to the synchronous tracking of flowering by a few pollinators (Linsley 1958), but to its ability to attract numerous pollinating taxa, only a few of which may be abundant in a given year.

It is impossible to manage for the welfare of this entire pollinator guild except in the most general way. The most promising out- look is to concentrate on eliminating or mitigating anthropogenic sins of commission by taking an ecosystem management approach (Tepedino et al. 1997). First, the detrimental effects of pest management programs on pollinators, such as insecticide spraying, must be considered. Penstemon penlandii occurs, in part, on public lands where cattle are grazed, and where livestock and grasshoppers are viewed as competitors for forage plants. Such areas may be sprayed with insecticides if grasshopper populations reach economically important densities (Anonymous 1987). Bee populations may be decimated during insecticide treatments, because all bees that have been studied are vulnerable to acephate, carbaryl, and malathion (Johanson et al. 1983), the only insecticides that are registered for grasshopper control on rangelands. At least some of $P$. penlandii's pollinators, bumblebees, are active from early spring to late fall. Thus, either an insecticide-free buffer zone must be maintained around $P$. penlandii habitat during the entire growing season, or bran bait treatments which are less detrimental to pollinators (Peach et al. 1994, 1995) should be used to reduce grasshopper numbers.

The nesting habitats of the pollinators must also be protected. The pollinator taxa of $P$. penlandii likely use a wide variety of nesting habitats. Although the nesting preferences of many Osmia species listed in Table 3 are unknown, other species of Osmia build their nests in wood and stems, on rocks, and in the ground (Hurd 1979). Bumblebees also vary in their preferred nesting sites. Bombus appositus builds its colonies at or below ground level, using materials such as dead grass, or abandoned rodent nests (Hobbs 1966). Bombus huntii usually builds its nests underground (Hobbs 1967). Anthophora bomboides and $A$. ursina are also ground nesters (Brooks 1983). Pseudomasaris vespoides builds its mud nests on or under rocks, or on twigs (Hurd 1979). Thus, persistent or widespread disturbance of soil and vegetation by off-road vehicles, road construction, wood- 
gathering, or overgrazing may negatively impact nesting sites of these pollinators (Sugden 1985). Efforts should be made to avoid or mitigate such disturbances.

\section{Acknowledgments}

We thank the U.S. Fish and Wildlife Service and the USDI Bureau of Land Management for their cooperation during this project, $\mathrm{M}$. Ritchard and $\mathrm{L}$. Palmer for allowing us to work on their land, W. Bowlin, Y. Wilder, and M. Sipes for field assistance, and E. Klomps for assistance in the lab. J. H. Cane (USDA-Logan) and A. D. Wolfe (Ohio State Univ.) critiqued an early version and helped us to improve our presentation. This project was funded by the USDA/APHIS Grasshopper IPM Project. It is USU Agricultural Experiment Station Publication No. 6093.

\section{References}

Alford D. V. (1975) Bumblebees. Davis-Poynter, London.

Anderson J., Jordon, L. A. (1992) Osterhout Milkvetch (Astragalus osterhoutii) and Penland Beardtongue (Penstemon penlandii). Recovery Plan. U.S. Fish and Wildlife Service, Denver Co. Anonymous (1987) Final environmental impact statement on the rangeland grasshopper cooperative management program. Washington, D. C.: Final Environmental Impact Statement, 87-1. USDA, Animal and Plant Health Inspection Service, Plant Protection Quarantine.

Barnes J. L. (1996) Reproductive ecology, population genetics, and clonal distribution of the narrow endemic Mirabilis macfarlanei (Nyctaginaceae). M. S. Thesis. Utah State University Logan.

Bateman L. (1980) Comparative floral biology of Penstemon eatonii and Penstemon cyananthus in central Utah: A preliminary study. Great Basin Naturalist 40: 268-272.

Beattie A. J., Breedlove D. E., Ehrlich P. R. (1973) The ecology of the pollinators and predators of Frasera speciosa. Ecology 54: 81-91.

Bobisud L. E., Neuhaus R. J. (1975) Pollinator constancy and survival of rare species. Oecologia 21: 263-272.
Bohart G. E., Nye W. P. (1960) Insect pollinators of carrots in Utah. Logan: Utah Agr. Exp. Stn. Bull. 419. $16 \mathrm{pp}$.

Brooks R. W. (1983) Systematics and bionomics of Anthophora: the Bomboides group and species groups of the New World. University of California Publications in Entomology, Vol. 98. University of California Press, Berkeley.

Cane J. H., Payne J. A. (1993) Regional, annual and seasonal variation in pollinator guilds: intrinsic traits of bees (Hymenoptera: Apoidea) underlie their patterns of abundance at Vaccinium ashei (Ericaceae) Ann. Entomol. Soc. Amer. 86: 577-588.

Charlesworth D., Charlesworth B. (1987) Inbreeding depression and its evolutionary consequences. Annu. Rev. Ecol. Syst. 18: 237268.

Cooper K. W. (1952) Records and flower preferences of masarid wasps. II. Polytropy or oligotropy in Pseudomasaris? (Hymenoptera: Vespidae). Amer. Mid. Nat. 48: 103-110.

Cripps C., Rust R. W. (1989) Pollen foraging in a community of Osmia bees (Hymenoptera: Megachilidae). Env. Entomol. 18: 582-589.

Crosswhite F. S., Crosswhite C. D. (1966) Insect pollinators of Penstemon series Graciles (Scrophulariaceae) with notes on Osmia and other Megachilidae. Amer. Mid. Nat. 76: 450-467.

Fiedler P. L., Ahouse J. J. (1992) Hierarchies of cause: Toward an understanding of rarity in vascular plant species. In: Fiedler P. L., Jain S. K. (eds.) Conservation biology. Chapman and Hall, London New York, pp. 23-47.

Geer S. M., Tepedino V. J. (1993) Breeding systems of the rare heliotrope milkvetch (Astragalus montii Welsh: Fabaceae) and two common congeners. In: Sivinski R., Lightfoot K. (eds.) Proceedings of the Southwestern Rare and Endangered Plant Conference. New Mexico Forestry and Resources Conservation Division. Misc. Publ. 2, Sant Fe, pp. 334-344.

Heinrich B. (1979) Bumblebee economics. Harvard University Press, Cambridge, MA.

Hobbs G. (1966) Ecology of spp. of Bombus Latr. (Hymenoptera: Apidae) in Southern Alberta V. Subgenus Subterraneobombus Vogt Can. Entomol. 98: 288-294.

Hobbs G. (1967) Ecology of spp. of Bombus Latr. (Hymenoptera: Apidae) in Southern Alberta VI. 
Subgenus Pyrobombus. Can. Entomol. 99: 1271-1292.

Hurd P. D. Jr. (1979) Superfamily Apoidea. In: Krombein K. V., Hurd Jr. P. D., Smith D. R., Burks B. D. (eds.) Catalog of Hymenoptera in America North of Mexico, Vol. 2. Smithsonian Institution Press, Washington, D. C., pp. 17412209.

Johansen C. A., Mayer D. F., Eves J. D., Kious C. W. (1983) Pesticides and bees. Env. Entomol. 12: $1513-1518$.

De Jong T. J., Waser N. M., Klinkhamer P. G. L. (1993) Geitonogamy: the neglected side of selfing. Trends Ecol. Evol. 8: 321--325.

Kampny C. M. (1995) Pollination and flower diversity in Scrophulariaceae. Bot. Rev. 61: 350-366.

Karron J. D. (1987) The pollination ecology of cooccurring geographically restricted and widespread species of Astragalus (Fabaceae). Biol. Cons. 39: 179-193.

Karron J. D. (1989) Breeding systems and levels of inbreeding depression in geographically restricted and widespread species of Astragalus (Fabaceae). Amer. J. Bot. 76: 331-340.

Kunin W. E., Shmida A. (1997) Plant reproductive traits as a function of local, regional and global abundance. Cons. Biol. 11: 183-192.

Lawson H. R., Tepedino V. J., Griswold T. L. (1989) Pollen collectors and other insect visitors to Penstemon haydenii S. Wats. In: Bragg T. B., Stubbendieck J. (eds.) Proc. 11th North American Prairie Conference. Univ. of Nebraska Printing. Lincoln, pp. 233-235.

Levin D. A. (1971) Competition for pollinator service: a stimulus for the evolution of autogamy. Evolution 26: 668-674.

Levin D. A., Anderson W. W. (1970) Competition for pollinators between simultaneously flowering species. Amer. Nat. 104: 455-467.

Linsley E. G. (1958) The ecology of solitary bees. Hilgardia 27: 543-599.

Mitchell R. J. (1988) Is Penstemon centranthifolius truly hummingbird pollinated? Crossosoma 15: $1-9$.

Moldenke A., Neff J. (1974) The Bees of California: a catalogue with special relevence to pollination and ecological research, Technical Report 74-3 (Part III of 3). Univ. of California Press, Santa Cruz.
Motten A. F., Campbell D. R., Alexander D. E., Miller H. L. (1981) Pollination effectiveness of specialist and generalist visitors to a North Carolina population of Claytonia virginica. Ecology 62: 1278-1287.

Müller A. (1996) Convergent evolution of morphological specializations in Central European bee and honey wasp species as an adaptation to the uptake of pollen from nototribic flowers (Hymenoptera, Apoidea and Masaridae). Biol. J. Linn. Soc. 57: 235-252.

Nielson R. (1998) Reproductive biology of the rare Harrington's beardtongue, Penstemon harringtonii. Utah State Univ, M. S. Thesis, Logan.

Orians G. H., Pearson N. E. (1979) On the theory of central place foraging. In: Horn D. J., Mitchell R. D., Stairs C. R. (eds.) Analysis of ecological systems. Ohio State Univ. Press, Columbus, pp. 154-177.

Peach M. L., Alston D. G., Tepedino V. J. (1994) Bees and bran bait: Is carbaryl bran bait lethal to alfalfa leafcutting bee (Hymenoptera: Megachilidae) adults or larvae? J. Econ. Entomol. 87: 311-317.

Peach M. L., Alston D. G., Tepedino V. J. (1995) Sublethal effects of carbaryl bran bait on nesting performance, parental investment, and offspring size and sex ratio of the alfalfa leafcutting bee (Hymenoptera: Megachilidae). Environ. Entomol. 24: 34-39.

Rabinowitz D. (1981) Seven forms of rarity. In: Synge H. (ed.) The biological aspects of rare plant conservation. Wiley, New York, pp. 205217.

Ramstetter J., Peterson K. M. (1984) Pollination biology of Penstemon lemhiensis (Keck) Keck and Crong. Amer. J. Bot. 71 (5, part 2): 87 (Abstract).

Sipes S. D., Tepedino V. J. (1995) Reproductive biology of the rare orchid, Spiranthes diluvialis: Breeding system, pollination, and implications for conservation. Cons. Biol. 9: 929-938.

Sipes S. D., Tepedino V. J. (1996) Pollinator Lost? Reproduction of the enigmatic Jones cycladenia. In: Maschinski J., Hammond H. D., Holter L. (eds.) Southwestern rare and endangered plants: Proc. of the 2nd Conf., pp. 158-166. Fort Collins CO: USDA Forest Service Rocky Mountain Forest and Range Experiment Station, Arizona Gen Tech. Rep. RM-GTR-283. 
Straw R. M. (1956) Floral isolation in Penstemon. Amer. Nat. 90: 47-50.

Straw R. M. (1972) A Markov model for pollinator constancy and competition. Amer. Nat. 106: 599-620.

Sudgen E. A. (1985) Pollinators of Astragalus monoensis Barneby (Fabaceae): new host records; potential impact of sheep grazing. Great Basin. Nat. 45: 299-312.

Sudgen E. A. (1986) Anthecology and pollinator efficacy of Styrax officinale subsp. Redivivum (Styracaceae). Amer. J. Bot. 73: 919-930.

Tepedino V. J. (1979) The importance of bees and other insect pollinators in maintaining floral species composition. Great Basin Nat. Mem. No 3: $139-150$.

Tepedino V. J. (1980) Resource availability and coexistence in shortgrass prairie bee guilds. Dissertation. University of Wyoming, Laramie.

Tepedino V. J. (1981) The pollination efficiency of the squash bee (Peponapis pruinosa) and the honeybee (Apis mellifera) on summer squash (Cucurbita pepo). J. Kansas Entomol. Soc. 54: 359-377.

Tepedino V. J. (1999) The reproductive biology of rare rangeland plants and their vulnerability to insecticides. In: Grasshópper integrated pest management user handbook. USDA APHIS Technical Bull. 1809 (in press).

Tepedino V. J., Sipes S. D., Barnes J. L., Hickerson L. L. (1997) The need for extended care in conservation: examples from studies of rare plants in the western United States. Acta Hort. 437: 245-248.

Torchio P. F. (1974) Mechanisms involved in the pollination of Penstemon visited by the Masarid wasp, Pseudomasaris vespoides (Cresson). PanPacific Entomol 50: 226-234.

Torchio P. F., Tepedino V. J. (1982) Parsivoltinism in three species of Osmia bees. Psyche 89: 221238.

Weber W. (1986) Penstemon penlandii. Spec. nov. Scrophulariaceae from Colorado. Phytologia 60: 459-461.

Addresses of the authors: V. J., Tepedino and T. L. Griswold, USDA ARS Bee Biology and Systematics Laboratory, Department of Biology, Utah State University, Logan UT, USA.; S. D. Sipes, Department of Biology, Utah State University, Logan UT, 84322-5310, USA. 